\title{
硬球押し込みによる多軸残留応力場の 応力腐食割れ試験法への適用性評価
}

\author{
井岡郁夫 \\ ${ }^{1}$ 日本原子力研究開発機構 \\ 2 株式会社三菱総合研究所 \\ 3株式会社化研
}

木内 清 $1, *$

滝沢真 $2^{2}$

伊 藤 剛 $\pm^{3}$

J. Japan Inst. Met. Mater. Vol. 78, No. 1 (2014), pp. 16-22

(C) 2014 The Japan Institute of Metals and Materials

\section{Evaluation of Applicability on Multi-Axis Residual Stress Formed by Hard Sphere Indentation for Stress Corrosion Cracking Test}

Ikuo Ioka ${ }^{1}$, Kiyoshi Kiuchi1 ${ }^{1, *}$, Masayuki Takizawa ${ }^{2}$ and Takeshi Ito ${ }^{3}$

${ }_{1}^{1}$ Japan Atomic Energy Agency, Naka-gun Ibaraki 319-1195

${ }^{2}$ Mitsubishi Research Institute, Inc., Tokyo 100-8141

${ }^{3}$ Kaken, Inc., Mito 310-0903

A multi-axis stress field is indispensable for quick and quantitative evaluation of stress corrosion cracking for constructional materials and weld joints of existing industrial plants. The applicability of multi-axis residual stress field formed by pushing of a hard sphere ball made of WC into stress corrosion cracking tests was evaluated.

The Brinell type hard sphere ball was stuffed into small flat-plate of type 304SS. The residual stress and displacement around the indentation were measured using an X-ray diffraction method and a displacement meter. Numerical analysis by the finite element method was conducted in order to compare with the experimental results. The numerical analysis was comparatively in agreement with the experimental results. A hard sphere ball diameter, a specimen holder hole diameter, specimen thickness, and an indentation depth were selected by numerical analysis to optimize the residual stress of specimen. The stress corrosion cracking test in chloride solution was performed using the specimen with optical residual stress condition. It is confirmed that the multi-axis residual stress field was useful in quick and quantitative stress corrosion cracking test by comparing the initiation of cracks with the distribution of residual stress obtained by numerical analysis. [doi:10.2320/jinstmet.J2013061]

(Received August 26, 2013; Accepted September 19, 2013; Published January 1, 2014)

Keywords: stress corrosion cracking, indentation techniques, Brinell type hard sphere ball, multi-axis residual stress, numerical analysis

\section{1. 緒言}

石油化学工業や原子炬施設等の構造材や機能材として使用 されているステンレス鋼の高経年化事象の多くは, 応力腐食 割れ (Stress Corrosion Cracking: SCC)であり, 稼働率の低 下や有用資源の喪失の主要因となっている。 それの防止対 策, 耐 SCC 合金の開発には, 機構解明と迅速定量的な SCC の評価試験法の高度化が不可欠となる.

SCC 評価試験に関しては, JIS や ASTM での規格化や提 案されている試験法として, 定歪法 (Uベント1-3), Cリン グ4,5), CBB: Creviced Bent Beam Test $\left.{ }^{6,7)}\right)$, 定荷重法8-10), 低歪速度法(SSRT: Slow Strain Rate Test ${ }^{11,12)}$ ), 破壊力学 的方法 (WOL: Wedge Opening Load ${ }^{13,14)}$, CT: Compact Tension ${ }^{15,16)}$ ) 等がある. 定歪法は, 試験方法も単純で, 実

\footnotetext{
* 現在 : 陎三菱総合研究所(Present address: Mitsubishi Research
} Institute, Inc.)
用模擬環境中で多数の試験が可能である一方，残留応力等の 力学的条件を規定しがたい. 定荷重法は, 短軸引張試験機等 で破断寿命を評価するが，多数の大型試験装置を必要とし， 時間もかかる. 低歪速度法 (SSRT) は, 皮膜破壊型の SCC には適用性が高く，材料間の SCC 抵抗性の基礎評価に適し ている. 破壊力学的方法は，欠陥存在下のき裂伝播速度を測 定する目的に限定される。一方，実機で経験される SCC の 多くは，材料の製造履歴や溶接継手等の微視的な複合組織の 違いが大きくかかわり，かつ多軸応力・ひずみ場で, 環境側 の腐食作用で生じるカタストロピックな現象である. そのた めに, 実機相当の応力・ひずみ場に対応した迅速定量的評価 試験が不可避である. 併せて, 試験体積を制限される放射線 照射場や，多数の候補材の迅速定量的選定には，従来の微小 試験技術は力学的条件が正確に規定できず，再現性の高い小 型試験法の開発が不可欠となっている.

本研究では, SUS304ULC 鋼製の小型平板試験片にブリ ネル型硬球 (WC 製)を押し込久 (圧痕押込法), 多軸応力・ひ ずみ場を負荷する手法を用いて，実用上重要な隙間条件も対 
応できる SCC 評価法を提案した，押し込み条件とそれによ り生じる圧痕周りの応力. 歪みの X 線回折測定と数值解析 を行い，圧痕押込法の再現性や力学的設定条件の妥当性を評 価した。ささに，選定した最適条件で製作した小型試験片を 用いて塩化物 SCC 評価試験を行い，SCC 評価法としての有 用性を検討した。

\section{2. 実 験 方 法}

\section{1 圧痕押込条件の選定}

供試材には, Table 1 に示す溶体化処理を施した SUS304ULC 鋼を用いた. 表面が供試材の圧延面になるよ うに厚肉材から板状試験片を切り出した. 試験片の形状は, Fig. 1(a)に示すように $30 \mathrm{~mm}$ 角で，厚さは $1,3,5 \mathrm{~mm}$ と し， 4 隅に $\phi 3 \mathrm{~mm}$ の試験片固定用の穴を配した。試験片 は, 表面を $0.5 \mu \mathrm{m}$ までバフ研磨し, 電解研磨を行い圧痕押 込試験に供した。圧痕押込試験では, ロードセルにブリネル 型 WC 硬球を取り付けた圧縮装置を整備して, 試験片に所 定の深さまで WC 硬球を押し込み，除荷した．この時の荷 重と変位を記録した。押し込久後の試験片には，Fig. 1(a) に示すように WC 硬球が接触した部分とその周りの WC 硬 球接触部の外側から試験片ホルダー台座穴部までの領域(変 形領域)が圧痕として形成され，主にこの圧痕部分に残留応 力が発生する. WC 硬球による変形部の力学的条件の再現性 および定量性を評価するため, 押し込久後の試験片の変形量 を測定するとともに，変形領域の残留応力を測定した．残留 応力を評価する面は, Fig. 1(b)に示すように WC 硬球が接 触する側の凹面とその裏面の凸面とした。 凸面の変形量測定 には, デジタル変位計を用いた. 残留応力測定は, 微小焦点 X 線応力測定装置 (PSPC-MSF：リガク)を用い, $2 \phi-\sin ^{2} \psi$

Table 1 Chemical composition and mechanical properties of applied specimens. (mass \%)

\begin{tabular}{lcccccccc}
\hline $\mathrm{Fe}$ & $\mathrm{Cr}$ & $\mathrm{Ni}$ & $\mathrm{Mn}$ & $\mathrm{Si}$ & $\mathrm{P}$ & $\mathrm{S}$ & $\mathrm{C}$ & $\mathrm{N}$ \\
\hline Bal. & 18.85 & 10.65 & 1.56 & 0.37 & 0.013 & 0.001 & 0.0012 & 0.005 \\
\hline & Young's modulus: $200 \mathrm{GPa}$ \\
Poisson's ratio: 0.3 & & & & & & \\
$0.2 \%$ & proof stress: $265 \mathrm{MPa}$ & & & & &
\end{tabular}

\section{(a) Sample}

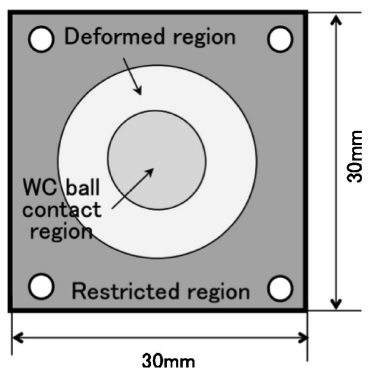

(b) Test Apparatus

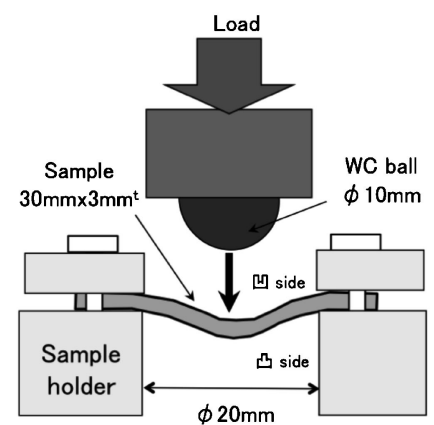

Fig. 1 Schematic view of test equipment. 凹 : subsidence, 凸： upheaval.
線図法により算出した. 応力係数は $-365.396 \mathrm{MPa} / \mathrm{deg}$ 用 いた。測定条件は，並傾法 $\psi$ 入射法により， $\mathrm{Cr}$ ターゲッ 卜，管電圧 $40 \mathrm{kV}$, 管電流 $30 \mathrm{~mA}$, コリメーター $\phi 1 \mathrm{~mm}$, 摇動角 $3^{\circ}$, 測角範囲 $145^{\circ} \sim 151^{\circ}$ で, 回折面は (311)を用い た.

\section{2 圧痕部残留応力の数値解析}

SCC 試験に用いる試験片形状および試験条件を選定する ため, 試験片と試験治具の幾何形状および WC 硬球の押し 込久深さをパラメータとした弾塑性応力解析により, 除荷後 の圧痕部の変形, 残留応力分布について解析を実施した. 解 析用パラメータには, 試験片板厚 (3 条件), WC 硬球径 (2 条件), 試験片ホルダー台座穴径 (2 条件), 押し込み深さ $(2$ 条件)の各組合せでの計 24 ケースとした。解析は, 沉用非 線形有限要素法解析ソフト ABAQUS を使用して, 静解析で 実施した. Fig. 2 に解析モデルのメッシュ図と WC 硬球押 し込み抢よび除荷時の応力解析の境界条件を示す。解析モデ ルは, 3 次元軸対称モデルである. 試験片と固定用ホルダー は一体もの, WC 硬球は剛体, 押し込み時の WC 硬球と試 験片との接触部の相互摩擦はゼロと想定して解析した。解析 に必要な材料の物性データは, Table 1 に示した縦弾性係 数, ポアソン比, 降伏応力と, 引張試験の真応力-真ひずみ 曲線を用いた。解析では, WC 硬球断面に一様の強制変位 (Y 方向)を与え, 目標の押し込久深さに到達後に WC 硬球 を試験片から離すことで除荷して, 凹面および凸面表面の圧 痕の周方向および半径方向の残留応力分布を評価した。

\subsection{SCC 評価試験}

ボルトで台座に固定した SUS304ULC 鋼板の中央に，応 力解析から選定した大きな引張応力が残留する条件で WC 硬球を所定深さまで押し込み，圧痕を導入した。この試験片 を用いて, JISG0576 に準じた 42\%塩化マグネシウム沸騰溶 液中で 100 時間の浸漬試験を実施した。試験後, SCC の発 生状況を確認するため, 圧痕部表面の光顕および SEM 観察 を行った。 また, 割れの発生位置と最大割れ長さを評価する ため, 蛍光浸透探傷検査法を用いた詳細観察を実施した。蛍 光浸透探傷法では, 乳化性蛍光浸透液を試験片表面に十分浸

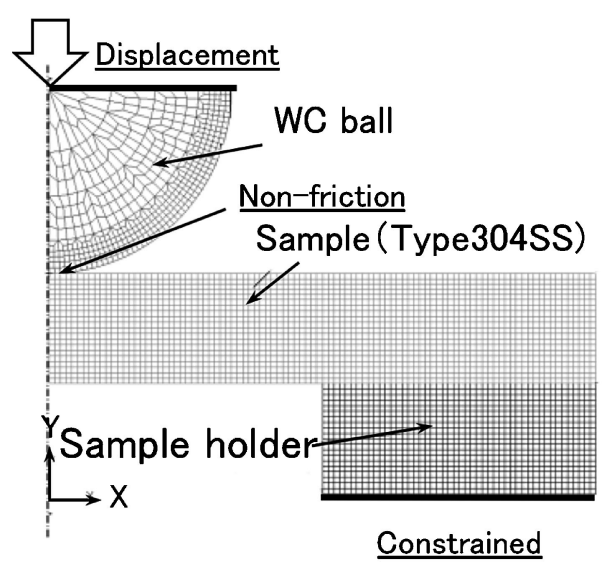

Fig. 2 Mesh model and boundary condition for FEM analyses. 
透させ，現像処理後，ブラックライト下で試験片表面の割れ 状況を観察した.

\section{3. 実験結果および考察}

\section{1 圧痕周りの数値解析}

Fig. 3 に圧痕部の残留応力の解析結果を示す. 解析条件 は, 試験片板厚 $1 \mathrm{~mm}$, WC 硬球直径 $10 \mathrm{~mm}$, 試験片ホル ダー台座穴径 $20 \mathrm{~mm}$, WC 硬球の押し込久深さ $2 \mathrm{~mm}$ であ る. Fig. 3(a)抢よび(b)は，図中に示すようにそれぞれ圧痕 に対する円周方向(周方向), 半径方向(径方向)の表面での残 留応力である. 試験片の凹面および凸面は, 図中の変形後の メッシュ図に対応する. また， ロは解析条件と同じ条件で圧 痕押达試験を実施した試験片について，X 線回折法により 得られた凹面での残留応力の值である.

解析によると圧痕部の WC 硬球接触部抢いて, 周方向の 残留応力は，凹面で引張の残留応力 $(\square)$ が中心から離れるに
従って増加し，凸面で圧縮の残留応力 $(\triangle)$ が発生し，中心か ら離れるに従って圧縮残留応力が大きくなった．径方向の残 留応力も同様な挙動を示し, 凹面で引張の残留応力 $(\square)$ が, 凸面で圧縮の残留応力 $(\triangle)$ が, 中心から離れるに従って増加 した。な拉，解析では WC 硬球との接触摩擦を考慮してい ないが，実際の残留応力の分布傾向は，この結果と同様と予 想される．圧痕部の変形領域に扮いて，周方向の残留応力 は，凹面で引張の残留応力 $(\square)$ が発生し外周に向かって減少 するが，試験片ホルダー台座穴近傍で，再度増加した。 凸面 では，発生する残留応力 $(\triangle)$ が外周に向かい圧縮から引張に なりピークをとった後圧縮になった． 径方向の残留応力は， 凹面で周方向と同様引張の残留応力 $(\square)$ が外側に向かって減 少し, 試験片ホルダー台座穴近傍で増加した。この試験片ホ ルダー台座穴近傍での増加は, 解析において試験片と試験片 ホルダー台座を一体化させたことにより顕著になったと思わ れる. 凸面では, 周方向と異なり圧縮の残留応力 $(\triangle)$ が，中 心から離れるに従って小さくなり，試験片ホルダ一台座穴近

\section{(a) Circumferential direction}

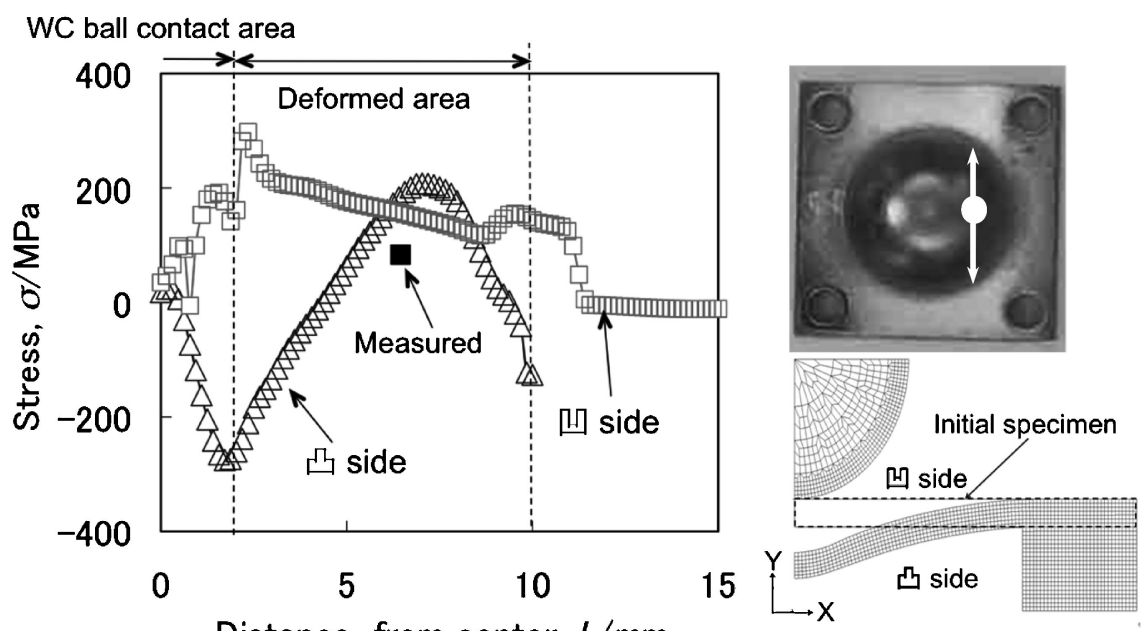

Distance from center. $L / \mathrm{mm}$

\section{(b) Radial direction}
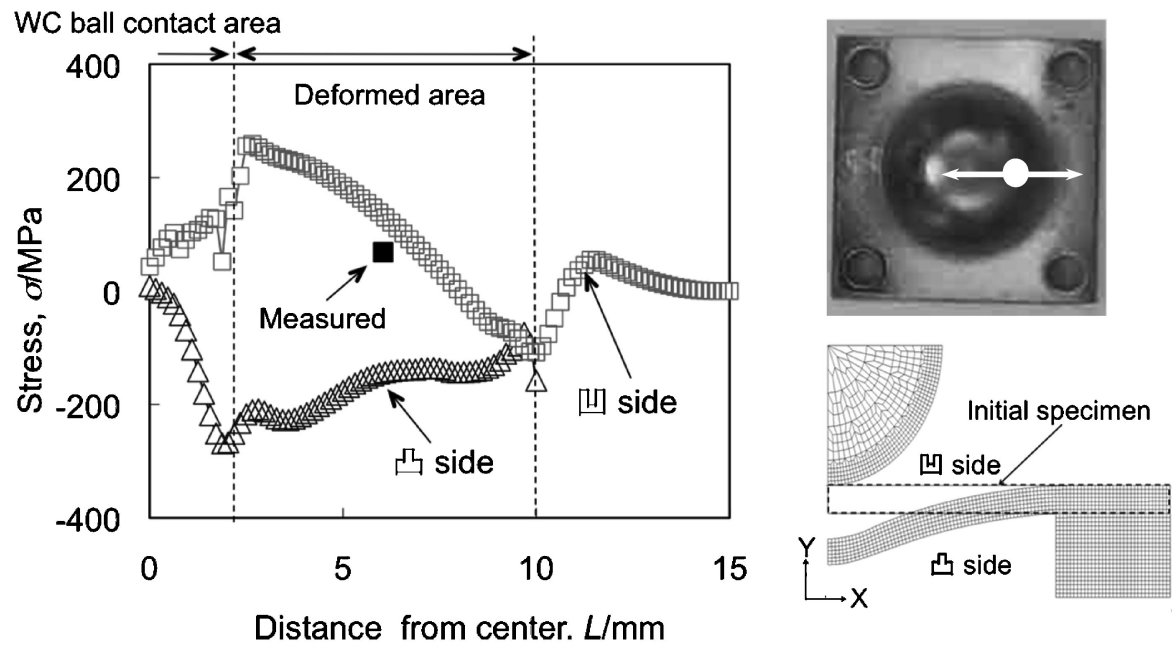

Fig. 3 Stress distribution on both surfaces of deformed specimen. 凹: subsidence, 凸: upheaval. (Thickness: $1 \mathrm{~mm}, \mathrm{WC}$ ball diameter: $10 \mathrm{~mm}$, Holder hole diameter: $20 \mathrm{~mm}$, Indentation depth: $2 \mathrm{~mm}$ ) 
傍でも圧縮であった。これら残留応力の発生傾向は, Bruni ら 17 が報告したバルジ加工した試験片に発生した残留応力 の解析および測定結果と同様な傾向であった。 また，X線 回折法による残留応力の測定結果は少ないが，解析結果と比 較的よく一致した. これら残留応力の分布は, 試験片板厚, WC 硬球等を変えても, 同様な傾向を示した. 圧痕部で SCC の原因となる引張残留応力が発生する箇所は, 周方向 では WC 硬球接触部の凹面側および変形領域の凹面側と凸 面側の一部, 径方向では WC 硬球接触部の凹面側および変 形領域の凹面側と考えられる。しかし, WC 硬球接触部で は, 接触部の摩擦により残留応力の発生が複雑化すると考え られるので, 材料の SCC 感受性を評価するには変形領域が 適していると考えられる.

押し込み後の試験片の変形状態を Fig. 4 に示す. Fig. 4 の縦軸は, 凸面表面の盛り上がり部分のデジタル変位計での 測定值である. 白抜きのシンボルは解析結果である. 塗り潰 しのシンボルが測定值であり，2４ 試験片の結果である.

$\mathrm{WC}$ 硬球の押し込久深さはすべて同じ $2 \mathrm{~mm}$ である. 試験片 の盛り上がり形状はほぼ軸対象で有り, 最大変形量は試験片 板厚の増加とともに，1.8, 1.6, $1.4 \mathrm{~mm}$ と減少した. 各厚さ

\section{(a) Thickness: $1 \mathrm{~mm}$}

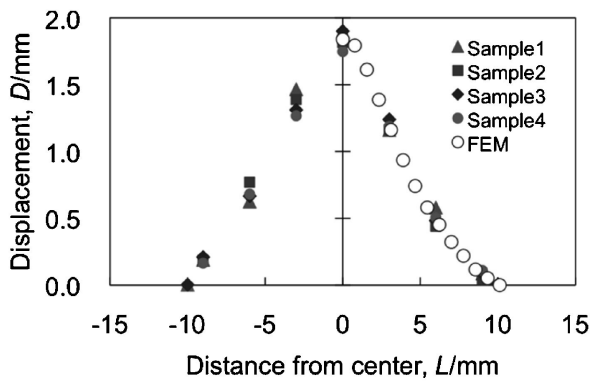

(b) Thickness:3mm

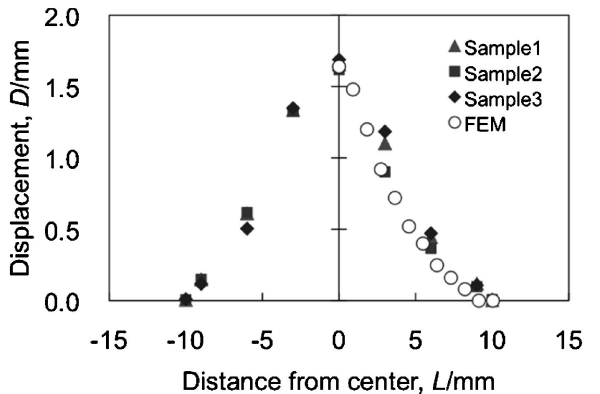

(c) Thickness:5mm

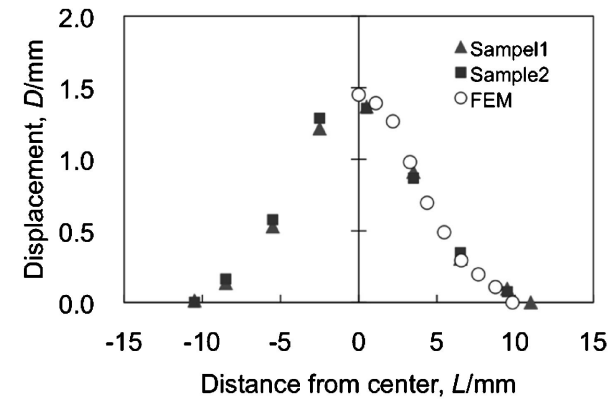

Fig. 4 Surface profile on upheaval side of deformed specimens. (WC ball diameter: $10 \mathrm{~mm}$, Holder hole diameter: 20 $\mathrm{mm}$, Indentation depth: $2 \mathrm{~mm}$ )
の試験片において, 変形量のバラツキは小さく, その値は解 析值とよく一致した. 以上, 残留応力と変形量の実測值と数 值解析結果は，略対応していることが確認できた.

\section{2 試験条件の最適化}

効率的な SCC 評価を実施するために必要な試験片に最大 引張残留応力が発生する試験条件を, 数值解析により選定す る. 解析条件は, 試験片板厚 $(1,3,5 \mathrm{~mm})$, WC 硬球径 $(\phi 10,15 \mathrm{~mm})$, 試験片ホルダー台座穴径 $(\phi 15,20 \mathrm{~mm})$, 押 し込久深さ $(1,2 \mathrm{~mm})$ とし，それぞれの組み合わせ 24 ケー スである。

試験片表面に発生する残留応力の WC 硬球の押し込久深 さ依存性を Fig. 5 に示す。一例として, 試験片板厚 $1 \mathrm{~mm}$, $\mathrm{WC}$ 硬球径 $10 \mathrm{~mm}$, 試験片ホルダー台座穴径 $20 \mathrm{~mm}$ の場合 の变形領域中央部(中心から約 $6 \mathrm{~mm}$ ) での結果を示した。凹 面で周方向に引張の残留応力 $(\square)$ が発生し, 押し込み深さの 増加とともに増加するが, 径方向では引張の残留応力が押し 込み深さの増加とともに減少する傾向にあった，凸面の周方 向の残留応力 $(\triangle)$ は, 凹面の結果と同様な結果を示したが, 径方向の残留応力 $(\boldsymbol{\Delta})$ は圧縮であり，押し込久深さの増加と ともに压縮応力は減少した. 試験片板厚が， $3 \mathrm{~mm}$ および 5 $\mathrm{mm}$ の場合もほぼ同様な結果が得られたが， 凸面の周方向の 残留応力は試験片板厚とともに小さくなり，試験片板厚 5 $\mathrm{mm}$ では押し込み深さ $2 \mathrm{~mm}$ の場合でも残留応力は圧縮とな った。よって，押し込久深さ $2 \mathrm{~mm} の$ 方が，試験片の凹面お よび凸面の周方向に発生する引張の残留応力は大きくなるこ とがわかった。

試験片表面に発生する残留応力に及ぼす試験片板厚の影響 を Fig. 6 によとめて示す. 結果は, WC 硬球径 $10 \mathrm{~mm}$, 試 験片ホルダー台座穴径 $20 \mathrm{~mm}$, WC 硬球の押し込久深さ 2 $\mathrm{mm}$ の場合である. 試験片板厚が厚くなると凹面の周方向お よび径方向とも引張の残留応力 $(\square, \square)$ 大きくなるが， 3 $\mathrm{mm}$ と $5 \mathrm{~mm}$ ではほぼ同じ值であった. 凸面の周方向拉よび 径方向の残留応力 $(\triangle, \boldsymbol{\Delta})$ は, 板厚の増加につれて小さくな る傾向にあった．周方向では試験片板厚の増加に伴い引張か ら圧縮に変わり, 径方向では試験片板厚 $1 \mathrm{~mm}$ の場合でも圧 縮であった．変形領域で引張の残留応力が生じる範囲が大き

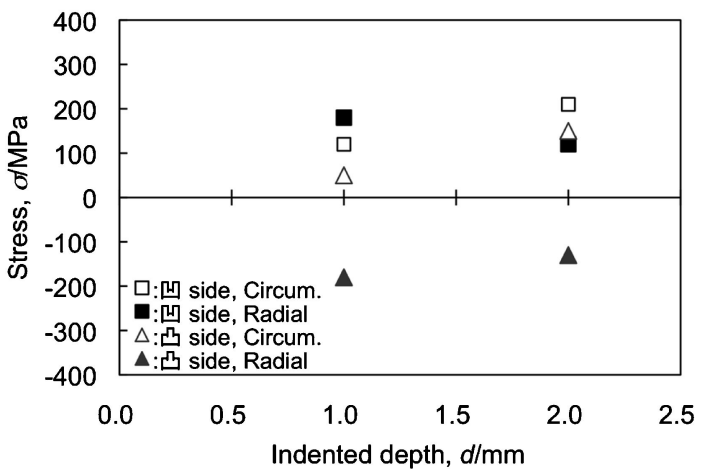

Fig. 5 Residual stress in circumferential and radial directions on both surfaces as a function of indented depth. 凹: subsidence, 凸: upheaval. (Thickness: $1 \mathrm{~mm}$, WC ball diameter: 10 $\mathrm{mm}$, Holder hole diameter: $20 \mathrm{~mm}$ ) 
いのは，試験片板厚が $1 \mathrm{~mm}$ の場合であるが，引張残留応力 が大きいのは試験片板厚が $3 \mathrm{~mm}$ または $5 \mathrm{~mm}$ の場合であ る. よって, 引張残留応力の範囲と応力值を考慮して, 試験 片板厚として $3 \mathrm{~mm}$ を選定した。

Fig. 7 に, 試験片ホルダー台座穴径と WC 硬球径の比率 を変化させた場合に試験片凹面および凸面に発生する周方向 および径方向の残留応力の解析結果をまとめた. 試験片板厚 $3 \mathrm{~mm}$, WC 硬球の押し込久深さ $2 \mathrm{~mm}$ に固定して, 解析を 行った. 硬球径/台座径比が小さくなると, 凹面の径方向引 張残留応力 (ロ) は大きくなるが, 凹面の周方向引張残留応力 (口)はでほとんぞ影響を受けない. 凸面の周方向残留応力

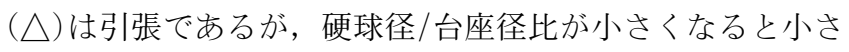
くなる傾向を示した. 一方, 凸面の径方向残留応力 $(\boldsymbol{\Delta})$ は圧 縮であり, 变化がほとんど認められなかった. WC 硬球径と 試験片ホルダー台座穴径に関しては, 凹面において高い引張 応力が発生しやすい $10,20 \mathrm{~mm}$ をそれぞれ選定した。

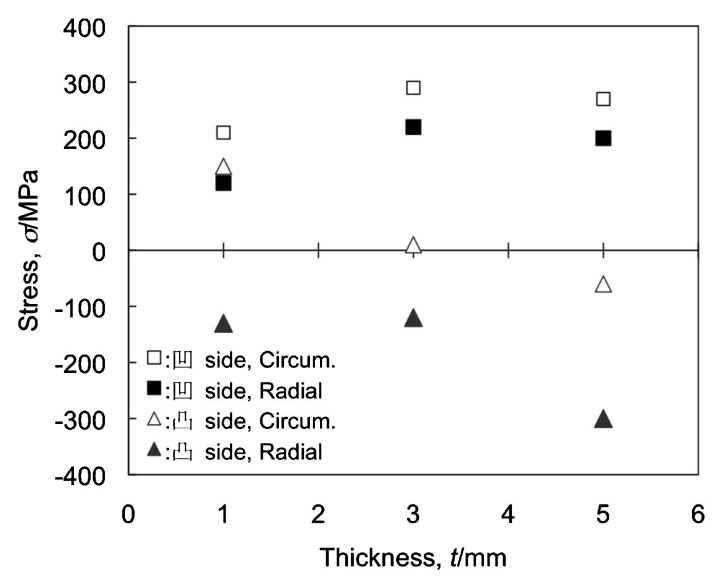

Fig. 6 Residual stress in circumferential and radial directions on both surfaces as a function of specimen thickness. 凹 : subsidence, 凸: upheaval. (WC ball diameter: $10 \mathrm{~mm}$, Holder hole diameter: $20 \mathrm{~mm}$, Indentation depth: $2 \mathrm{~mm}$ )

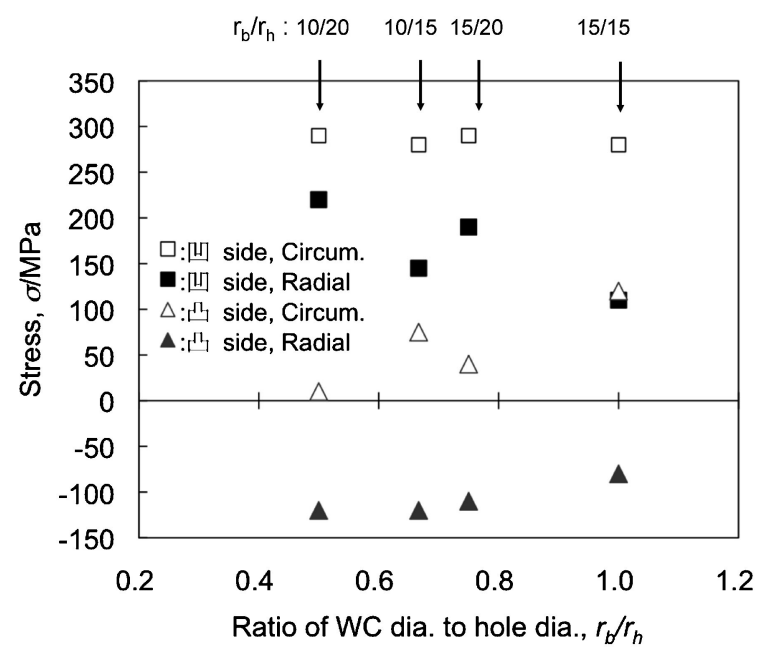

Fig. 7 Residual stress in circumferential and radial directions on both surfaces as a function of the ratio of WC ball diameter to hole diameter. 凹: subsidence, 凸: upheaval. (Thickness: 3 $\mathrm{mm}$, Indentation depth: $2 \mathrm{~mm}$ )

\subsection{SCC 評価試験}

数值解析により選定した条件より，板厚 $3 \mathrm{~mm}$ の SUS304ULC 鋼を用いて, 試験片ホルダー台座穴径 $20 \mathrm{~mm}$, $\mathrm{WC}$ 製の $10 \mathrm{~mm}$ 径の硬球による押し込久深さ $2 \mathrm{~mm}$ の圧痕 試験片を作製した。この試験片を用いて沸騰 $42 \%$ 塩化マグ ネシウム溶液中で SCC 評価試験を実施して, 蛍光浸透探傷 検査法による割れの観察結果を Fig. 8 に示す. 凹面および 凸面の中央の直径抢よそ $5 \mathrm{~mm}$ の領域は WC 硬球の直接接 触した拘束部分である. また，4方向の角に見える穴は, 押 込試験時に試験片を固定したものである. Fig. 8(a)の凹面 では, 周方向残留応力に起因する径方向の割れが観察され,

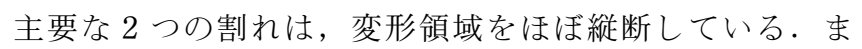
た, 径方向残留応力に起因する周方向の割れは主に WC 硬 球接触部外側および試験片ホルダー台座穴接触部外側に，ほ ぼ全周にわたって発生している.一方, Fig. 8(b)の凸面で は, 数本の径方向の割れが観察され, それらの割れすべては 変形領域の両端まで達していない. 割れの長さも極端な違い はなく, 略均等に分布している. なお, 周方向の割れは観察 されなかった。

Fig. 8 の蛍光浸透探傷検査法により観察された割れについ て, 径方向および周方向の割れの発生方向と全長さをなとめ た結果を, Fig. 9 に示す. 周方向の割れは, 分岐している割 れを含めて評価した. 図中のカッコ内の数字は観察された割 れの本数である. 周方向割れは, WC 硬球押し込久時の塑性

(a) Surface of subsidence side

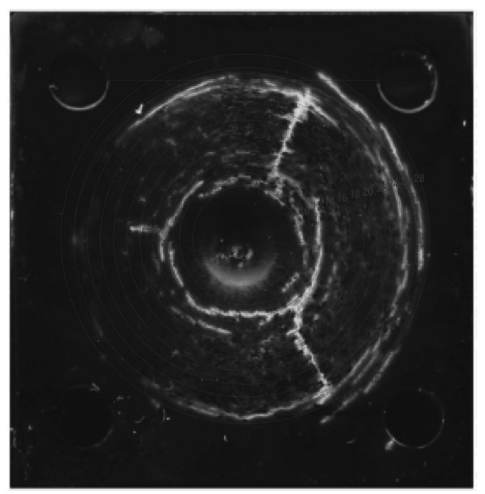

(b) Surface of upheaval side

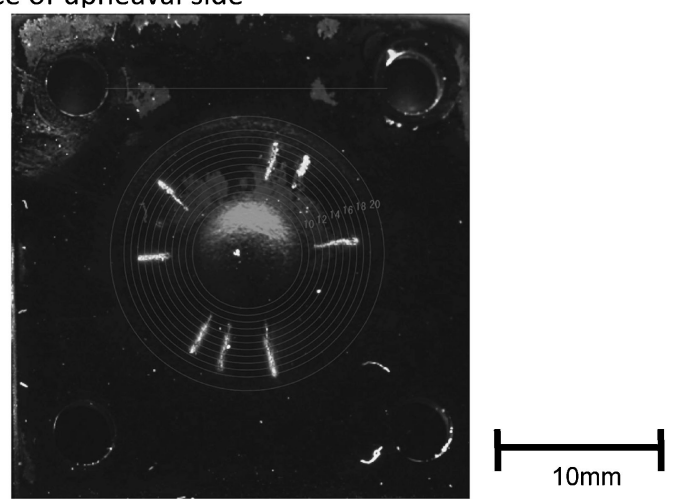

Fig. 8 Crack on surface of deformed specimens using fluorescent cracking inspection method. (SUS304ULC, Thickness: 3 $\mathrm{mm}$, WC ball diameter: $10 \mathrm{~mm}$, Holder hole diameter: $20 \mathrm{~mm}$, Indentation depth: $2 \mathrm{~mm}$ ) 
変形後, 解放時に引張残留応力の生じる凹面にの久観察され た. 径方向割れに比べ発生数は多いが，平均長さは約 1.6 $\mathrm{mm}$ と短い。一方, 径方向割れは, 凹面および凸面で，その 分布に大きな違いがあったが，本数と平均長さ(凹面 : 2.1 $\mathrm{mm}$, 凸面 : $2.7 \mathrm{~mm}$ ) はほぼ同じであった. 凹面の変形領域 のほぼ中間の位置で観察された割れの光顕観察結果を Fig. 10 に示す。試験片表面は酸化物や塩化物の析出物に覆われ ていた．周方向抢よび径方向の割れは，今までに報告18)さ れているようにほとんどが結晶粒を貫通する粒内貫通割れで あった，周方向割れは，径方向に垂直なものと若干傾いたも のが観察された. 凹面の応力解析から, 周方向の引張応力と それより小さい径方向の引張応力の二軸の残留応力が存在 し, 板材の製造履歴に伴う金属集合組織がかかわる結晶粒界 の方向に依存した成分偏析の違い等による SCC 感受性の異 なりが複雑に関係した割れが生じているものと推察される.

これらの観察された凹面および凸面での割れの方向や位置 について, 数值解析により得られた引張残留応力の発生位置 と大きさとの対応関係を Fig. 11, Fig. 12 にまとめた. 凹面 での周方向の割れ分布を示す Fig. 11 の上図は，X軸が圧痕 中心からの距離, $Y$ 軸が割れの個数, $Z$ 軸が割れ長さを示し ている. Fig. 11 の下図は, 解析により得られた径方向の残 留応力である. 引張残留応力は, 変形領域および圧痕周辺に ピークがあり, この引張残留応力分布と周方向の割れの発生

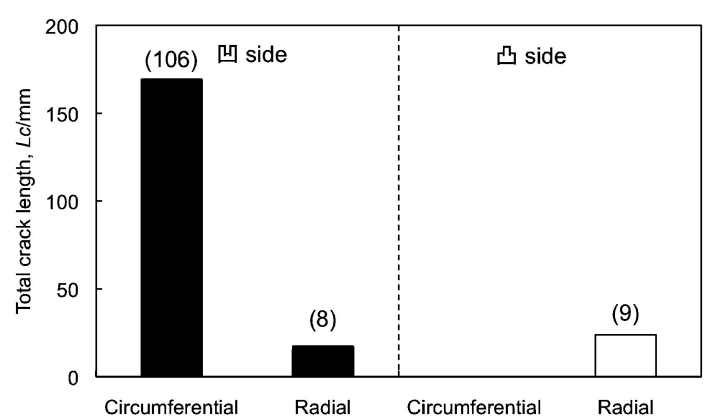

Fig. 9 Total crack length on both surface of deformed specimen. 凹: subsidence, 凸: upheaval. (SUS304ULC, Thickness: $3 \mathrm{~mm}$, WC ball diameter: $10 \mathrm{~mm}$, Holder hole diameter: $20 \mathrm{~mm}$, Indentation depth: $2 \mathrm{~mm}$ )

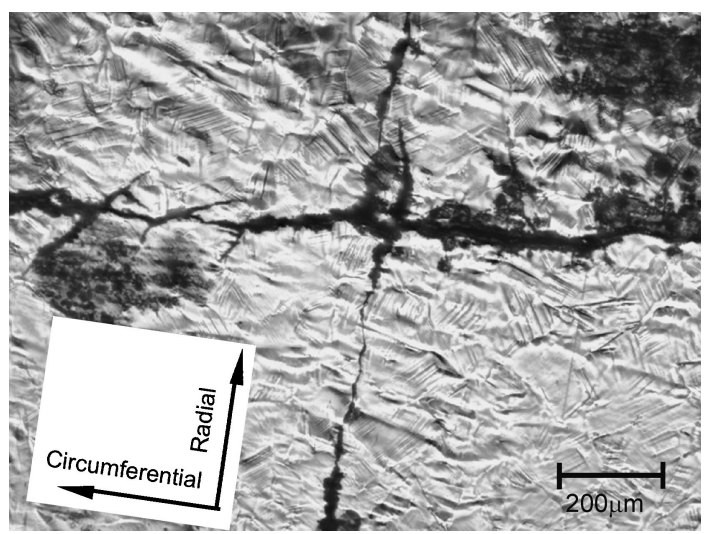

Fig. 10 Surface (subsidence side) observation of deformed specimens by microscope. (SUS304ULC, Thickness: $3 \mathrm{~mm}$, Hole diameter: $20 \mathrm{~mm}$, WC ball diameter: $10 \mathrm{~mm}$, Depth: 2 $\mathrm{mm}$ )

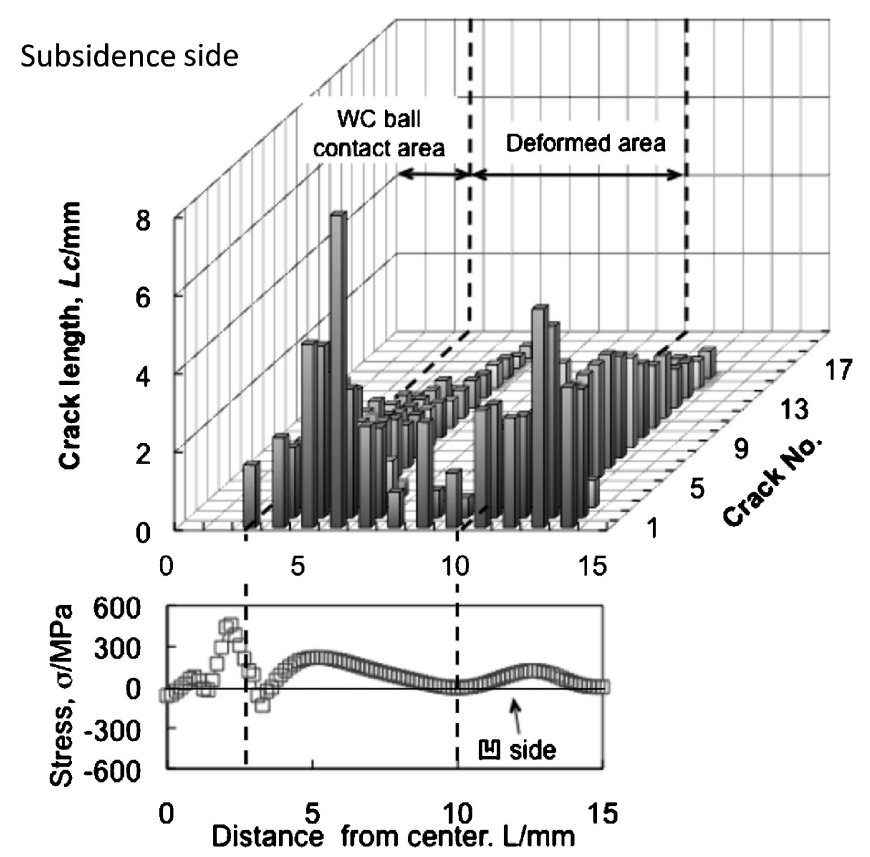

Fig. 11 Comparison between distributions of circumferential cracks and profiles of stress distribution calculated with evaluation code. 凹: subsidence.

\section{(a) Subsidence}

side
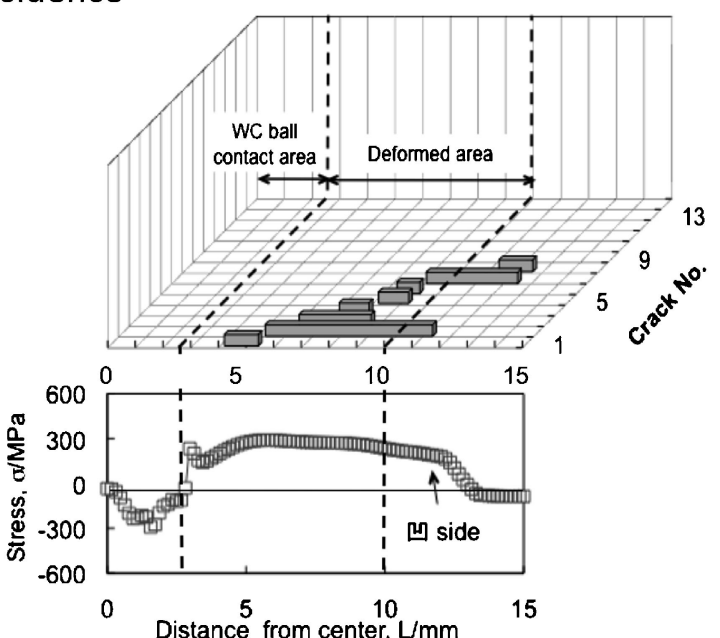

(b) Upheaval side

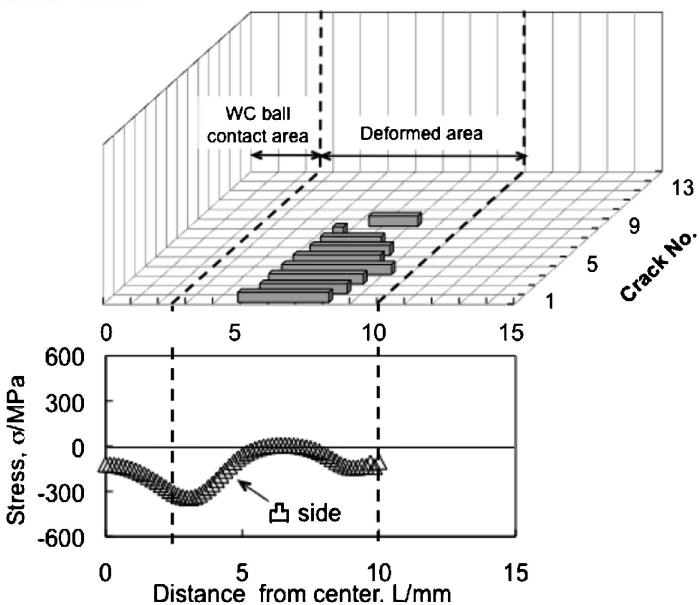

Fig. 12 Comparison between distributions of radial cracks and profiles of stress distribution calculated with evaluation code. 凹: subsidence, 凸: upheaval. 
はよく対応している．WC 硬球接触部には，凹面側に周方向 および径方向に引張残留応力が存在するが，当該部分には割 れが観察されず，接触部の大きな変形拘束が原因と推察され る.Uベンド法での強変形部に割れが少ない事象に似てい る. 凹面抢よび凸面での径方向の割れ分布を示す Fig. 12 (a) および (b)の上図では， $X$ 軸は圧痕中心からの距離であり割 れ長さにも対応し， $Y$ 軸が割れの個数を示している.なお, $Z$ 軸は Fig. 11 と対応させるとともに, 結果を見やすくする ために示している. Fig. 12(a) および(b)の下図は, 解析に より得られた周方向の残留応力である. 凹面での引張残留応 力は, 変形領域から圧痕の周辺 $3 \mathrm{~mm}$ までほぼ均一に生じて おり, この残留応力分布に対応して径方向の割れは変形領域 および圧痕周辺に発生した. 凸面では, 值は小さいが変形領 域のみに引張残留応力が生じている。 また，径方向の割れの 発生は, 変形領域のみであり, 引張残留応力分布とよく一致 した。

以上, SCC 試験により, 割れの発生状況と押し込みによ り導入した残留応力との対応関係を得ることができた。これ により，SCC 評価試験法として，圧痕押込法により多軸の 残留応力場を導入する小型試験片技術は, 数值解析との組合 せにより SCC 感受性を再現性のよい迅速定量的評価が可能 と考えられる。

\section{4. 結論}

実機構造材や溶接継手部の SCC 迅速定量評価法として, 多軸応力場を再現しやすいブリネル型硬球の圧痕押込法を適 用した小型試験片を用いた SCC の評価試験を行い，以下の 知見を得た。

圧痕部の変形形状および X 線回折法による残留応力の測 定と有限要素法による数值解析を行い，小型試験片に再現性 の高い多軸残留応力場を設定できることを確認した. SUS304ULC 小型試験片について, 試験片板厚, WC 硬球 径, 試験片ホルダー台座穴径等をパラメータとした数值解析
を実施して，引張残留応力を生じる最適条件を選定した，選 定した条件で製作した試験片を用いて, 塩化物 SCC 評価試 験を行い, 割れの発生状況と押し込久部の残留応力分布を比 較し, 良好な相関関係を得た。これにより, ブリネル型 WC 硬球による圧痕押込法は, 多軸残留応力場の規定下での実機 材のSCC の迅速定量評価法として有効な技術であること明 確にした。

今後は, 多種類の機械的特性の大きく異なる材料や腐食環 境条件での当該試験技術の適用性を評価して, SCC の標準 試験法として確立していくことが必要である.

\section{文献}

1) W. Yang, M. Zhang, G. Zhao and J. Congleton: Corrosion 47 (1991) 226-233.

2) C. Garcia, F. Martin, P. De Tiedra, J. A. Heredero and M. L. Aparicio: Corros. Sci. 43(2001) 1519-1539.

3) F. Ferrer, E. Schille, D. Verardo and J. Goudiakas: J. Mater. Sci. 37 (2002) 2707-2712.

4) S. S. Hwang, H. P. Kim, D. H. Lee, U. C. Kim and J. S. Kim: J. Nucl. Mater. 275(1999) 28-36.

5) W. Yang, Z. P. Lu, D. L. Huang, D. S. Kong, G. Z. Zhao and J. Congleton: Corros. Sci. 43(2001) 963-977.

6) G. S. Was, H. H. Tischner and R. M. Latanision: Metall. Trans. A 12 (1981) 1397-1408.

7) R. A. Page: Corrosion 39 (1983) 409-421.

8) H. H. Le and E. Ghali: J. Appl. Electrochemi. 22(1992) 396403.

9) A. Oehlert and A. Atrens: Corros. Sci. 38(1996) 1159-1169.

10) R. Nishimura: Corros. Sci. 49(2007) 81-91.

11) M. Kodama, J. Morisawa, S. Nishimura, K. Asano, S. Shima and K. Nakata: J. Nucl. Mater. 212(1994) 1509-1514.

12) G. Furutani, N. Nakajima, T. Konishi and M. Kodama: J. Nucl. Mater. 288(2001) 179-186.

13) J. MBarson: Eng. Fract. Mech. 3(1971) 15-25.

14) G. Sui, E. A. Charles and J. Congleton: Corros. Sci. 38(1996) 687-703.

15) E. Kikuchi, M. Itow, J. Kuniya, H. Sakamoto, M. Yamamoto and A. Sudo: Corrosion 53 (1997) 306-311.

16) M. Gomez-Duran and D. D. Macdonald: Corros. Sci. 48 (2006) 1608-1622.

17) C. Bruni, M. Celeghini, M. Geiger and F. Gabrielli: Int. J. Adv. Manuf. Technol. 33(2007) 929-939.

18) J. D. Harston and J. C. Scully: Corrosion 26(1970) 387-392. 